\title{
下鼻道血管線維腫例
}

\author{
大越 俊夫・金沢 博俊・且井 信郎

\section{Angiofibroma in the Nasal Cavity; A Case Report} \\ Toshio Ogoshi, Hirotoshi Kanazawa and Nobuo Usui \\ (Toho University)
}

Angiofibroma in the nasal cavity is very rare.

Our patient was a 28-year-old female with right nasal obstruction and tearing of the right eye. A nodular mass was seen ocupying the right inferior meatus. X-ray examination showed clear paranasal sinuses.

Under general anesthesia, the tumor was removed with contact type Nd-YAG laser through a perimaxillary approach. The tumor, which originated from the posterior half of the right inferior nasal turbinate, measured $28 \times 17 \times 7 \mathrm{~mm}$.

The histopathological diagnosis was angiofibroma.

The patient was followed for 28 months after the operation and showed no recurrence of the tumor.

Key words: angiofibroma, nasal cavity, laser surgery

はじめに

頭頸部領域の血管線維腫は鼻咽腔に発生する ことが多く, 鼻腔, 副鼻腔での発生はきわめて 稀である．血管線維腫は病理組織学的には良性 であるが，易出血性であり再発も多い，今回我 我は，一側性の鼻閉，流涙を主訴とした下鼻道 に発生した血管線維腫の一症例を経験したので 報告する。

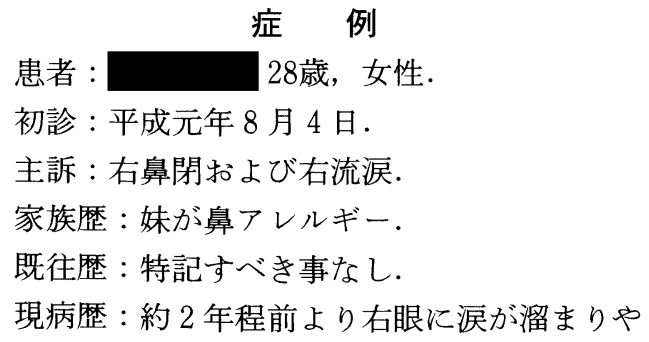

すく近医眼科で沪囊炎といわれていた。 平成元 年 7 月中旬より右鼻閉出現，同時に右鼻漏あり, 鼻をかむと疼痛もあった。近医耳鼻咽喉科受診 し右鼻腔にポリープを指摘され，精査をすすめ られ当科を受診した。

初診時全身所見: 体格栄養は中等度で, 特に 異常は認めなかった.

局所所見 : 前鼻鏡所見では, 右下鼻道に暗赤 色のやや硬い腫瘤を認めた（図 1 ). 鼻腔底扣よ び下鼻道外側壁と内側壁の下側部には瘉着はな く, 下鼻甲介の上方が基部であると思われた. 痂皮, 白苔はなく, 易出血性であったが止血は 容易であった．下鼻甲介は内側上方へ圧迫され ていた，後鼻鏡所見では腫瘤の後端がわずかに 見えたが，鼻咽腔は正常であった。 


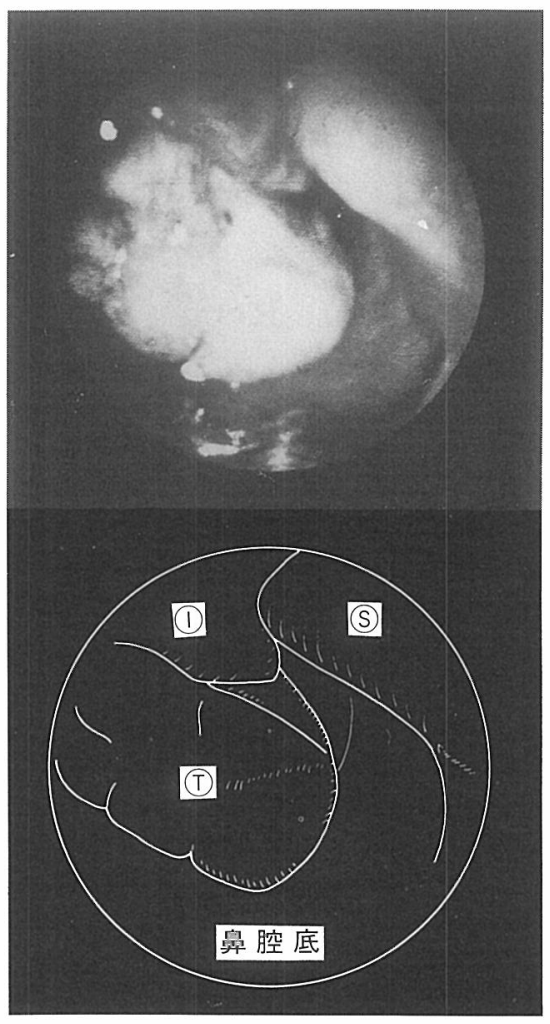

図 1 鼻内所見と炎のシェーマ

(S)右側への番中隔の弯曲

(I)腫瘤により上方へ圧排された右下鼻甲介 (T)右下鼻道内の腫瘤

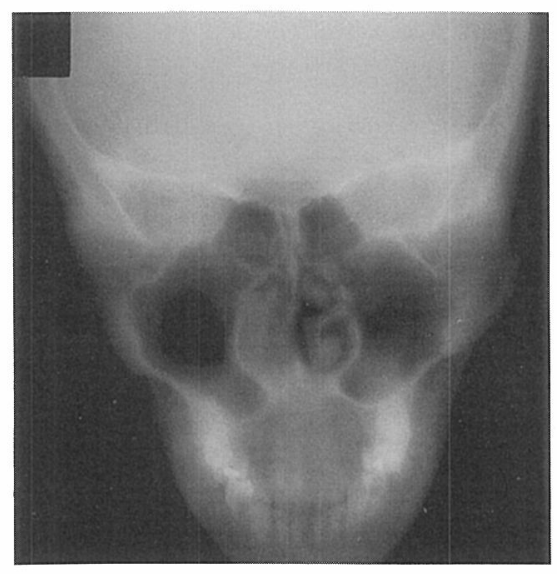

図 $2 \mathrm{X}$ 線断層所見
一般検査成績 : 体重 $43 \mathrm{~kg}$, 身長 $153 \mathrm{~cm}$, 血 压 $106 / 74 \mathrm{mmHg}$ ，脈拍 $74 / \mathrm{min}$. 末梢血液検 査では赤血球 464 万, 白血球 4600 , 血色素量 $13.9 \mathrm{~g} / \mathrm{dl}$, へマトクリット值 $42.7 \%$, 血小板数 27.4 万, 血沈值は $4 \mathrm{~mm} /$ 時でめり, その他の血清, 生化学的検查でも特に異常は認められなかった。 また17-KS，17-OHCS も正常範囲であった。

鼻 $\mathrm{X}$ 線抒よび CT 検査: X線検査では右下鼻 道に陰影が認められた。副鼻腔に陰影はなかっ た(図 2)。CT スキャンでは右下鼻甲介粘膜の 肥厚が見られ，造影剂にて不均一に造影された。 しかし周囲の骨破壞はなかった（図３）。X線所 見同様, 副鼻腔には異常は認められなかった。

$\mathrm{RI}$ 検査 : $\mathrm{Ga}$ シンチグラフィーでは右側鼻腔 に一致してガリウムの集積を認めた。

病理組織学的所見: 外来で試験切除を行なっ た. 出血は少量であった，組織診断は若年性血 管線維腫であった。

手術所見：平成元年 10 月 9 日全身麻酔下㳗 上顎洞的に手術を行なった. 腫瘍は下鼻道の上 部, 中央より後方にかけ広基性の茎をもち，右 下鼻道を充満していた。鼻腔底, 下鼻道外側壁, 下鼻甲介外側粘膜との瘉着はなかった。接触型 Nd-YAGレーザーを使用し周团粘膜を切開し 剝離した. 後上方の切開はやや困難であったが, 腫瘍を周囲の粘膜を含め一塊として全摘出でさ

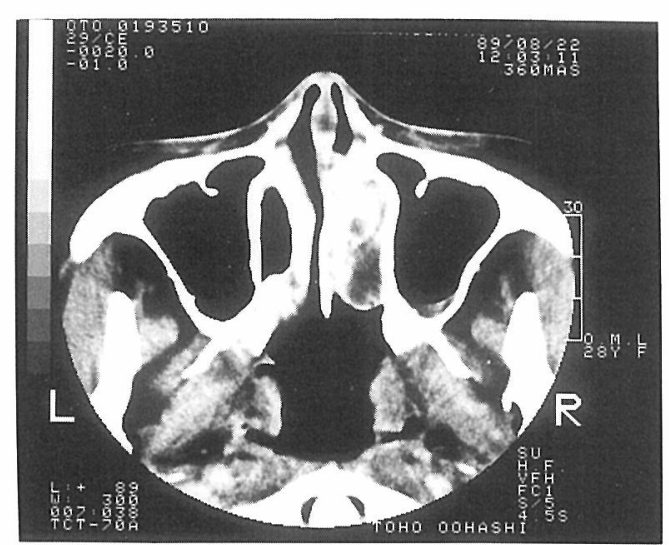

図 3 造影 CT 所見(水平断面) 
た、腫瘍の栄養血管ははっきりしなかった。腫 瘍摘出後, 止血执よび再発防止を目的として, レーザーで周囲を充分に焼玓した，完全に止血 されたことを確認した後, ゼルフォーム®をあ て，テラマイシン®軟膏を塗布した平ポリーゼ で圧迫し手術を終了した。出血量は約 $200 \mathrm{ml}$ であった。

病理組織診断：摘出された腫瘤は $28 \times 17 \times 7$ $\mathrm{mm}$ で, 灰白色のやや軟らかい部分と扊色の弾 性のある硬い部分よりなっていた(図 4)。多列 線毛円柱上皮で覆われた豊富な血管に加兄，小 血管の著しい増生, 周囲には線維の増生も見ら れ，血管線維腫と診断された(図 5 ).

術後経過: 術後経過は良好で, 7 日目にタン ポンを抜去した。術後流涙, 鼻閉は消失し, 眼 科での鼻涙管の通水検査も良好であった。術後 2 週間で退院した. 術後 2 年半経過した現在,

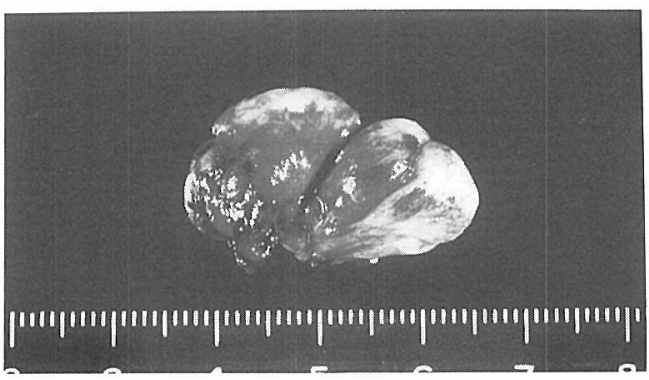

図 4 摘出腫瘍

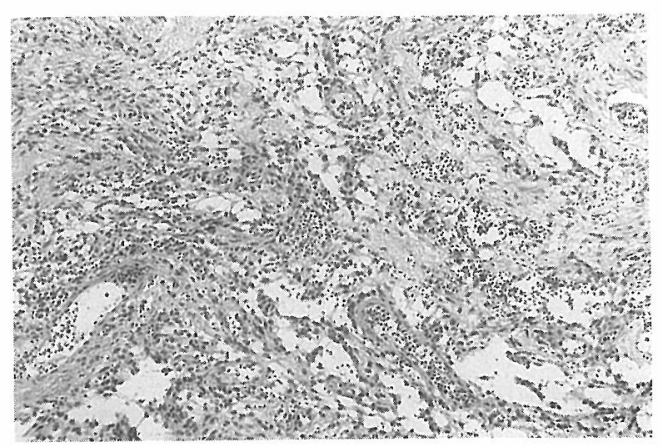

図 5 病理組織所見 HE 染色 $(\times 200)$
再発を認めない。

\section{考察}

鼻咽腔血管線維腫の発生頻度について, 志水 ら ら²は1：17000と報告して抒り，好発年齢は 古市ら4)の報告によると10歳代に多いとされ， さらに性別は241：18 と男性に多いとしている。 一方, 鼻腔領域での血管線維腫の発生はきわめ て稀35)6)であり，本邦に和ける鼻腔領域の血管 線維腫の報告は, 今回我々が調べ得た範囲では 本症例を含めて 24 例であり, 記載不明の 2 例を 除いた22例の平均年齢は25.0歳であり, 男女比 は16:6であった(表 1)。

鼻咽腔血管線維腫の発生, 成因については, 炎症説，ホルモン説，血管腫の特殊型とする説， 奇形説など種々の説がある. Nelaton?) は鼻咽 腔天蓋の骨膜から発生するといい, Brunner8) によれば血管線維腫は通常 fascia basilalis の存 在する鼻咽腔後壁から鼻咽腔天蓋さらに口蓋骨, 篩骨, 一部翼状突起の内側板から発生するとい い, Schiff ${ }^{9)}$ は鼻咽腔血管線維腫は頭部が形成 される過程で血管に富んだ鼻甲介組織が異所性 飞鼻咽腔骨膜で発育したものであろらとし，性 ホルモンと腫瘍内の線維血管成分との関連につ いて報告している，我々の症例では小血管の著 しい増生とこれら血管周囲の線維の増生がみら れたが，17-KS，17-OHCSの副腎皮質ホルモン は正常であった。また，Osborn ${ }^{10)}$ は血管破綻 による微小出血により反応性増殖をきたした一 種の組織奇形であろらと述べている.

Coenen ${ }^{11)}$ は本腫瘍の拡がり方により basilar type, sphenoethmoidal type, pterygomaxillar type, tubal typeの 4 型に分類した.

本症の臨床症状としては鼻閉, 反復性鼻出血 が多いが，本例では下鼻道の鼻涙管開口部の腫 瘤による排泄障害からくる流涙も訴えた。確定 診断としては試験切除が明確であるが，大量出 血をきたす場合もあり，施行されていない場合 も少なくない11)5)。今回は前鼻鏡下に処置中の 出血がそれ程多くなく，また止血も容易であっ 
たことより試験切除を行なった。

鼻咽腔の血管線維腫の治療法としては, 手術 療法の他に性ホルモン療法 ${ }^{12)}$, 放射線療法13) が 行なわれて拉り, 志水ら1)の詳細な報告がある. 最終的には外科的な完全摘出が最も良いとされ ているが，この場合の問題点は出血 ${ }^{14)}$ と再発 ${ }^{15)}$ であろう． $5000 \mathrm{ml}$ を超える大出血や出血死の 報告もある4). CT, MRI, angiographyなどの 術前検査の進歩に伴い, 腫瘍の栄養血管の結禁, また最近はゼルフォーム®による選択的血管塞 栓術が行なわれ，出血量の減少に成果をあげて (るる1617)。 その他凍結手術 ${ }^{18)}$, レーザーによる 治療 ${ }^{19)}$ の報告もある.

鼻, 副鼻腔領域に発生する血管線維腫は腫瘍 の位置関係にもよるが，鼻咽腔に比し一般に手
術可能な場所と考える. 今回の症例では前鼻鏡 所見, 鼻腔ファイバースコープ所見, 造影 CT 所見で, 腫瘍が下鼻道に局在しており発生部位 が下鼻甲介下面の中央部々予測できたこと，ま た生検時に出血が少なかったことから術前に特 別な処置はとらなかったが，経上顎洞的にアプ ローチし腫瘍の注ぼ全貌を明視下に置き得たこ と, また手術時に接触型 Nd-YAGレーザーを 使用したことは, 完全摘出をはかるらえで, ま た出血を抑觉るら壳で有用であったと考劣る。

Nd-YAG レーザーは発振波長 $1.06 \mu \mathrm{m}$ のレー ザーで, 凝固, 止血にすぐれて拈り,ファイバー を介しての操作が可能なことから内視鏡レー ザー手術に応用され, 耳鼻咽喉科領域でも使用 されている20). 最近はNd-YAGレーザーの先

表 1 鼻腔血管線維腫の報告例

\begin{tabular}{|c|c|c|c|c|c|c|}
\hline 症例 & 報告者 & 報告年 & 性 & 年歯 & 主 & 発生部位 \\
\hline 1 & 古市ら & 1973 & 男 & 21 & & 中鼻道 \\
\hline 2 & 野垣ら & 1977 & 女 & 19 & 鼻出血, 鼻閉 & 中鼻道 \\
\hline 3 & 平出ら & 1978 & 男 & 13 & 鼻出血, 鼻閉 & 鼻中隔 \\
\hline 4 & 古川ら & 1980 & 男 & 21 & 鼻閉 & 中鼻道 \\
\hline 5 & 中原ら & 1983 & 男 & 17 & & 中鼻甲介 \\
\hline 6 & 桜井ら & 1983 & 男 & 37 & 鼻出血 & 鼻中隔 \\
\hline 7 & "I & " & 女 & 37 & 鼻出血 & 中鼻道 \\
\hline 8 & 増田ら & 1984 & 男 & 13 & & 鼻中隔 \\
\hline 9 & 和久田ら & 1984 & 男 & 20 & & 鼻中隔 \\
\hline 10 & 大河内ら & 1985 & 男 & 56 & 鼻出血, 鼻閉 & 鼻中隔 \\
\hline 11 & " & " & 男 & 40 & 鼻閉, 鼻出血 & 下鼻道 \\
\hline 12 & " & " & 男 & 37 & 鼻閉, 鼻出血 & 鼻中隔 \\
\hline 13 & " & " & 女 & 27 & 鼻出血 & 鼻中隔 \\
\hline 14 & 藤野ら & 1985 & 男 & 42 & 鼻閉, 鼻出血 & 中鼻道 \\
\hline 15 & 坂倉ら & 1986 & 男 & 16 & 鼻閉 & 鼻中隔 \\
\hline 16 & 牧野ら & 1986 & 女 & 14 & 鼻閉 & 下鼻甲介 \\
\hline 17 & 吉田ら & 1987 & 男 & 16 & & 中鼻甲介 \\
\hline 18 & 渡辺ら & 1987 & & & & 中鼻甲介 \\
\hline 19 & " & " & & & & 中鼻道 \\
\hline 20 & 中川ら & 1987 & 男 & 24 & 鼻出血 & 鼻中隔 \\
\hline 21 & 妙中ら & 1988 & 女 & 15 & 鼻閉, 顔面圧迫感 & 中鼻道 \\
\hline 22 & 広田ら & 1988 & 男 & 9 & いびき, 鼻閉 & 鼻腔側壁 \\
\hline 23 & 鈴木ら & 1990 & 男 & 27 & 鼻閉 & 下鼻甲介 \\
\hline 24 & 自験例 & 1992 & 女 & 28 & 鼻閉, 流涙 & 下鼻甲介 \\
\hline
\end{tabular}


端に種々の形のセラミック性のプローブの取り 付けが可能な接触型 Nd-YAGレーザーが開発 され使用されている21122). 本症例もこの接触型 Nd-YAGレーザーを用いたが，接触型である ので通常のメスと同様に操作ができること，ま た種々のプローブを使い分けることにより切開， 凝固がよりスムーズに行なえた。

本腫瘍は病理組織学的には良性であり, 生命 に対する予後は一般に良いとされる。しかしな がら周冊組織への浸潤傾向が強く, 再発率も高 く, 臨床的には治療困難で, 悪性腫瘍に殉じて 取り扱われている. 本例では幸いにも現在再発 は認めないが，外来にて経過観察中である.

\section{まとめ}

右鼻閉，右流沪を主訴とした右下鼻甲介外側 から発生した血管線維腫に対し，レーザー手術 が有用であった28歳女性の一例を報告した。 あ わせて鼻腔内に発生した血管線維腫に対する文 献的考察も行なった.

稿を終わるにあたり, 病理学的検索について御教 示賜った東邦大学大橋病院病理学教室の涉谷和俊講 師, 若山恵助手に感謝致します.

本論文の要旨は1991年 7 月の第53回耳鼻咽喉科臨 床学会(札幌)および1991年12月の第 7 回アジア・オ セアニア耳鼻咽喉科咽喉学会議(香港)にて発表した.

\section{文献}

1）志水雄輔, 藤谷哲造, 中川 嚴, 他 : 上咽頭線 維腫. 耳喉 $45: 889 \sim 900,1973$.

2) Härmä RA : Nasopharyngeal angiofibroma. Acta Otolaryngol Suppl $146: 1 \sim 74,1958$.

3）大河内幸男, 小針仁美, 大梘好正, 他 : 鼻腔血 管線維腫の 4 症例. 耳鼻臨床 補10：133～140, 1987.

4）古市暢夫, 金森邦彦, 大藤周彦, 他 : 巨大な鼻 咽腔血管線維腫の 2 例と本邦報告例についての 文献的考察. 耳喉 $45: 875 \sim 890,1972$.

5）平出文久, 松原 宏: 若年性鼻腔血管線維腫の 1 例. 耳喉 50 : 991 997, 1978.

6) 桜井一生, 高須昭彦, 岩田重信, 他 : 鼻腔血管 線維腫の 2 例.耳鼻臨床 $77: 1599 \sim 1604,1984$.
7) Nelaton $\mathrm{M}$ : Polype fibreux de la base crane; cansidertions generales. Gaz Hop 26 : 22, 1953.

8) Brunner $H:$ Nasopharyngeal fibroma. Ann Otol Rhinol Laryngol $51:$ 29 65, 1942.

9) Schiff $M$ : Juvenile nasopharyngeal angiofibroma ; a theory of pathogenesis. Laryngoscope 69 : 981 1016, 1959.

10) Osborn DA: The so-called juvenile angiofibroma of the nasopharynx. J Laryngol 73 : 295 315, 1959.

11) Coenen $H$ : Das Basalfibroid (typisches Nasenrachen Fibroma) ein Skelettumor. München Med Wochenschr $70: 829 \sim 833,1923$.

12）古内一郎, 坂下桂之助, 道下秀雄, 他: 鼻咽腔 血管線維腫について(特に性ホルモンとの関 係). 日耳鼻 $69: 1192 \sim 1197,1966$.

13）上田 潤, 原一夫, 矢富泰治, 他: 放射線治 療が奏効した若年性線維血管腫の 2 例. 臨放 $29: 499 \sim 501,1984$.

14）山際幹和, 坂倉康夫, 間島雄一, 他: 蝶形洞血 管線維腫の一症例. 耳鼻臨床 $67: 1103 \sim 1107$, 1974.

15）白幡雄一, 児玉 実, 足川力雄: 鼻科領域血管 腫の臨床像. 耳展 $21: 430 \sim 439,1978$.

16）坂倉健二, 間島雄一, 坂倉康夫, 他: 鼻中隔血 管線維腫の一症例. 耳鼻臨床 $80: 899 \sim 904$, 1987.

17）小関芳宏, 新井寧子, 古内一郎, 他: 鼻咽腔血 管線維腫一手術江打施超選択的血管造影塞 栓術の効果について一. 日耳鼻 $89: 1047 \sim 1050$, 1986.

18) Smith MF, Boles $R$ and Worke $W$ : Cryosurgical technique in removal of angiofibromas. Laryngoscope $74: 1071 \sim 1080$, 1964.

19）林 治博, 長谷川哲, 伊東真人, 他: 若年性鼻 咽腔血管線維腫の 1 症例. 耳鼻臨床 $76: 2515$ $\sim 2519,1983$.

20）大越俊夫, 堀井恵子, 臼井信郎, 他: NdYAGレーザーにより治療した気切後狭窄の 1 例. 小児耳 $10: 49 \sim 51,1989$.

21）徳重栄一郎, 昇 卓夫, 大山 勝, 他: 鼻咽腔 血管線維腫 一接触型 Nd: YAG レーザーの使 用経験一. 耳鼻臨床 $83: 1415 \sim 1421,1990$. 
22）昇卓夫：接触型レーザーメスの利用法.

JOHNS 5 : 755〜 759, 1989.

原稿受付 : 平成 4 年 6 月 29 日

原稿採択: 平成 4 年 8 月 13 日

別刷請求先 : 大越俊夫

厂153 東京都目黒区大橋2-17-6

東邦大学医学部耳鼻咽喉科学第二講座) 